\title{
UPAYA PENINGKATAN KINERJA GURU MELALUI PEMBINAAN KONSEP DAN IMPLEMENTASI MEDIA PRESENTASI MICROSOFT POWERPOINT DI MAN 1 HSU
}

\author{
RAUDLATUL MUNAWARAH \\ MAN 1 HSU, Amuntai Tengah, Kabupaten Hulu Sungai Utara, Kalimantan Selatan \\ e-mail :warah711@gmail.com
}

\begin{abstract}
Currently, there are more teachers who only use textbooks as the only medium of teaching and learning. For this reason, an alternative solution is needed by developing Microsoft PowerPoint as a teaching and learning medium. The objectives of the study are to develop positive attitudes and generate teachers' interest in the use of informatics education media into teaching and learning activities. The research used school action research method conducted in 2 cycles. The data was analyzed by using percentage technique and was qualitatively descripted. The results showed that the performance of teachers in teaching by making, presenting material using the media presentation of Microsoft Power Point in MAN 1 HSU is categorized as active and very good. The lowest score for the assessment of teaching activities is $59(81.94 \%)$ and the highest is $70(97.22 \%)$. While the lowest value for the assessment of manufacture and presentation is 52 (86.66) and the highest is $60(100 \%)$.
\end{abstract}

Keywords: teacher performance, presentation media, Microsoft PowerPoint

\begin{abstract}
ABSTRAK
Saat ini masih banyak guru yang hanya menggunakan buku pelajaran sebagai satu-satunya media pembelajaran. Untuk itu perlu alternatif pemecahan masalah dengan mengembangkan Microsoft PowerPoint sebagai media pembelajaran. Penelitian ini bertujuan untuk mengembangkan sikap positif dan membangkitkan minat guru terhadap penggunaan media pendidikan informatika ke dalam kegiatan proses belajar mengajar. Penelitian ini menggunakan metode penelitian tindakan sekolah dengan 2 siklus. Data dianalisis dengan menggunakan teknik persentase dan dideskripsikan secara kualitatif. Hasil penelitian menunjukan bahwa kinerja guru dalam mengajar dengan membuat dan menyajikan materi menggunakan media presentasi microsoft powerpoint di MAN 1 HSU termasuk kedalam kategori aktif dan sangat baik. Nilai terendah untuk penilaian kegiatan mengajar $59(81,94 \%)$ dan tertinggi 70 (97,22\%), sedangkan nilai terendah untuk penilaian pembuatan dan penyajian $52(86,66)$ dan tertinggi $60(100 \%)$.
\end{abstract}

Kata Kunci : kinerja guru, media presentasi, Microsoft Powerpoint

\section{PENDAHULUAN}

Penemuan-penemuan baru dalam bidang ilmu pengetahuan dan teknologi telah membawa pengaruh yang besar dalam bidang pendidikan. Akibat dari pengaruh tersebut telah mendorong berbagai usaha pembaharuan untuk meningkatkan mutu pendidikan. Saat ini ternyata masih ada guru yang hanya menggunakan buku pelajaran sebagai satu-satunya media pembelajaran. Untuk itu dibuatlah alternatif pemecahan masalah dengan mengembangkan Microsoft PowerPoint sebagai media pembelajaran (Hartini, 2017). Tujuan pengembangan 
Microsoft PowerPoint ini adalah untuk membantu guru dalam proses belajar mengajar dalam rangka mencapai tujuan pembelajaran yang telah ditetapkan.

Menurut Sanjaya (2010) kinerja guru berkaitan dengan tugas perencanaan, pengelolalan pembelajaran dan penilaian hasil belajar siswa. Sebagai perencana, maka guru harus mampu mendesain pembelajaran yang sesuai dengan kondisi di lapangan. Sebagai pengelola maka guru harus mampu menciptakan iklim pembelajaran yang kondusif sehingga siswa dapat belajar dengan baik, dan sebagai evaluator maka guru harus mampu melaksanakan penilaian proses dan hasil belajar siswa. Lebih lanjut Brown dalam Sardiman (2003) menjelaskan tugas dan peranan guru, antara lain: menguasai dan mengembangkan materi pelajaran, merencanakan dan mempersiapkan pelajaran sehari-hari, mengontrol dan mengevaluasi kegiatan belajar siswa. Kinerja guru adalah wujud prilaku suatu kegiatan guru dalam proses pembelajaran yaitu bagaimana seorang guru merencanakan pembelajaran, melaksanakan kegiatan pembelajaran dan menilai hasil belajar (Harjanto, 2008).

Berdasarkan uraian di atas maka rumusan masalah dalam penelitian ini adalah sebagai berikut: Bagaimana kemampuan guru menggunakan media presentasi Microsoft Powerpoint dalam proses kegiatan belajar mengajar di MAN 1 HSU? Bagaimana guru membuat dan menyajikan media presentasi Microsoft Powerpoint dalam kegiatan belajar mengajar di MAN 1 HSU?

Microsoft PowerPoint adalah sebuah program komputer untuk presentasi yang dikembangkan oleh Microsoft di dalam paket aplikasi Microsoft Office. Aplikasi ini sangat banyak digunakan, baik di kalangan perkantoran, para pendidik, siswa, dan trainer. Dimulai pada versi Microsoft Office System 2003, Microsoft mengganti nama dari sebelumnya Microsoft PowerPoint saja menjadi Microsoft Office PowerPoint. Versi terbaru dari PowerPoint adalah versi 12 (Microsoft Office PowerPoint 2007), yang tergabung ke dalam paket Microsoft Office System 2007. Pengertian umum dari Microsoft PowerPoint 2007 Merupakan program aplikasi untuk presentasi. Untuk membuat presentasi diawali dengan membuat kerangka atau outline, kemudian menyiapkan slide yang baik dengan tampilan yang menarik. Perkembangan berikutnya pada seri Microsoft office manampilkan Power point 2010. Microsoft Office PowerPoint dapat memberikan kelebihan, yaitu pada setiap halaman presentasi (slide), dapat disisipkan komponen- komponen yang berupa teks, grafik, gambar, foto, suara dan film, sehingga dapat menarik perhatian peserta didik yang akhirnya berdampak pada hasil belajar. Selain itu, Microsoft Office PowerPoint juga dapat dihubungkan dengan LCD sehingga lebih menarik untuk pembelajaran kelas besar. Fungsi dari Microsoft PowerPoint atau program presentasi adalah untuk pengajar atau pembicara seminar yang biasanya membahas materi untuk dipresentasikan. Microsoft PowerPoint dapat juga digunakan untuk membantu merancang dan menyajikan presentasi. Presentasi yang dibuat dapat berisi tampilan teks maupun grafis yang terbagi dalam slide.

\section{METODE PENELITIAN}

Penelitian ini merupakan penelitian tindakan sekolah. Tujuan utama dari penelitian tindakan sekolah adalah untuk memperbaiki/meningkatkan praktek pembelajaran secara berkesinambungan, sedangkan tujuan penyertaannya adalah menumbuhkan budaya meneliti di kalangan guru (Mukhlis, 2008). Kepala sekolah bertindak sebagai observer atau pengamat penelitian, sementara yang melaksanakan dan bertanggung jawab penuh terhadap penelitian ini adalah guru mata pelajaran di MAN 1 HSU. Dalam penelitian ini peneliti bekerjasama dengan guru mata pelajaran. Kehadiran peneliti sebatas memberikan konsep dasar pembelajaran dan bimbingan yang kemudian diterapkan oleh guru mata pelajaran di kelas.

Lokasi penelitian ini di MAN 1 HSU Provinsi Kalimantan Selatan pada bulan Oktober sampai dengan November tahun pelajaran 2018/2019. Subyek penelitian adalah 11 orang guru mata pelajaran (22\% dari 48 orang guru yang ada) yang dipilih secara random 
berdasarkan jumlah mata pelajaran yang disajikan di MAN 1 HSU sesuai dengan Kurikulum 2013. Penelitian ini menggunakan model penelitian tindakan berbentuk Spiral (Kemmis, McTaggart, \& Nixon, 2014). Setiap siklus meliputi rencana, act (tindakan), observation (pengamatan), dan reflect (refleksi). Dalam penelitian ini digunakan instrumen yang terdiri dari: Silabus, Rencana Pelaksanaan Pelajaran (RPP), Lembar Observasi Kegiatan Belajar Mengajar, dan Lembar Observasi Media Presentasi Microsoft Powerpoint. Instrumen penelitian menggunakan lembar observasi. Terdapat 18 kegiatan pembelajaran guru yang diobservasi dari 3 aspek kegiatan pembelajaran, seperti yang disajikan pada Tabel 1. Penilaian hasil observasi menggunakan skor 1 - 4 , di mana skor $1=$ kurang baik, skor 2 = cukup, skor $3=$ baik, skor 4= baik sekali. Analisis data menggunakan teknik persentase.

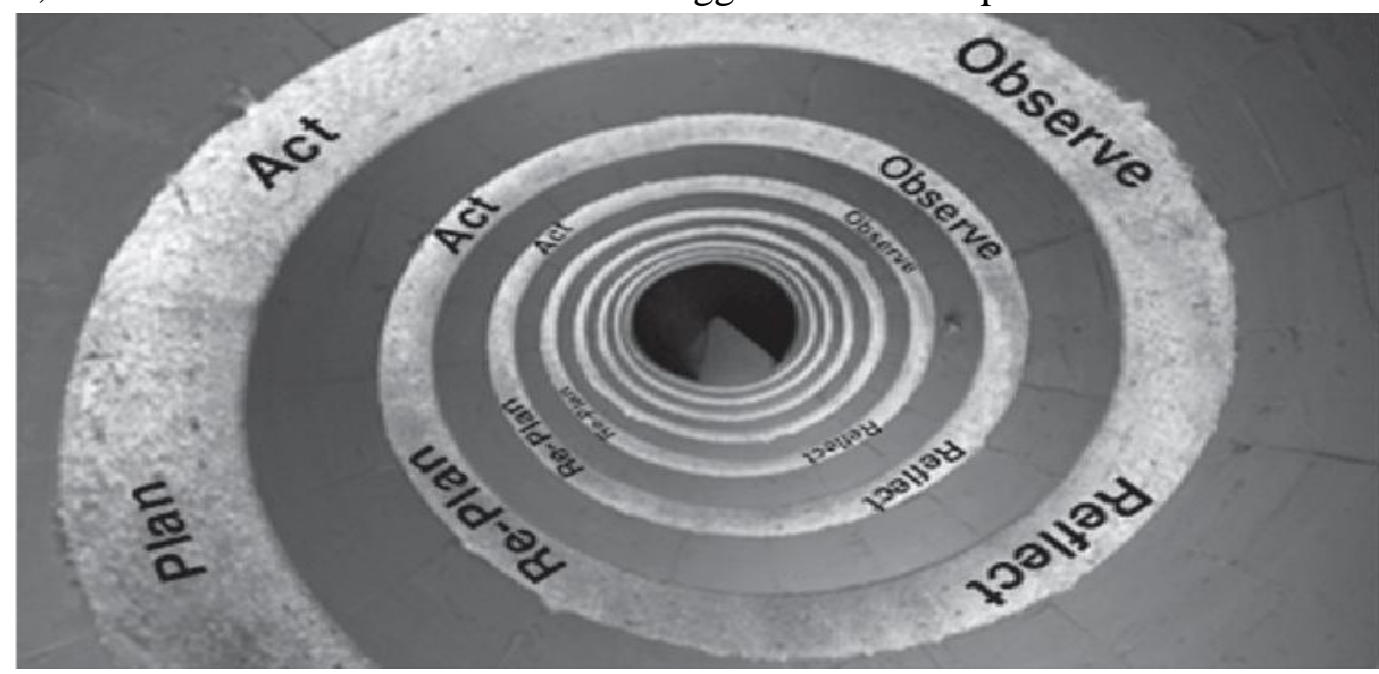

Gambar 1. Langkah-langkah pelaksanaan penelitian tindakan model Spiral (Kemmis, McTaggart, \& Nixon, 2014)

Tabel 1. Kegiatan pembelajaran yang diobservasi

\begin{tabular}{lll}
\hline Kegiatan & No & Jenis kegiatan \\
\hline Pendahuluan & 1 & Memberi salam dan absensi \\
2 & Apersepsi dan motivasi \\
3 & Menuliskan Tujuan Pembelajaran dengan PPt \\
4 & Menuliskan indikator dengan PPt \\
& 5 & Persiapan materi pelajaran \\
Inti & 6 & Penyajian materi sesuai urutan \\
& 7 & Model pembelajaran sesuai materi \\
& 8 & Penggunaan PPt sebagai media pembelajaran \\
& 9 & Penggunaan alat peraga pembelajaran \\
& 10 & Mengelola kelas dengan baik \\
& 11 & Membimbing/fasilitator siswa \\
& 12 & Memberi waktu bertanya kepada siswa \\
& 13 & Memakai bahasa Indonesia dengan baik \\
& 14 & Berpenampilan rapi dan sopan \\
& \\
& 15 & Membuat kesimpulan \\
& 16 & Memberi tugas/PR \\
17 & Menutup pelajaran dan memberi salam \\
18 & KBM sesuai alokasi waktu \\
\hline
\end{tabular}




\section{HASIL DAN PEMBAHASAN}

Penelitian tindakan sekolah ini dilakukan terhadap kinerja 11 orang guru yang mengajar pada mata pelajaran (1) Pendidikan Ekonomi, (2) PPKn, (3) Bahasa Inggris, (4) Geografi, (5) Kimia, (6) Matematika, (7) Sejarah, (8) Biologi, (9) Sosiologi, (10) Bahasa Indonesia, dan (11) Fisika.

\section{Perencanaan}

Pada tahap ini peneliti melakukan pemeriksaan kelengkapan perangkat pembelajaran guru mata pelajaran yang akan diobservasi. Perangkat pembelajaran terdiri dari silabus, RPP, LKS dan media presentasi microsoft power point serta alat-alat pembelajaran yang mendukung. Kegiatan perencanaan berjalan baik pada semua mata pelajaran yang diobservasi.

\section{Pelaksanaan}

Pelaksanaan supervisi tindakan kelas dilaksanakan pada hari dan waktu yang berbedabeda. Mata pelajaran Pendidikan Al-Qur'an Hadits dan Fiqih dilaksanakan pada tanggal 13 Oktober 2018. Mata pelajaran SKI dan Bahasa Indonesia dilaksanakan pada tanggal 22 Oktober 2018, mata pelajaran Bahasa Inggris dan Matematika dilaksanakan pada tanggal 3 November 2018, mata pelajaran Kimia pada tanggal 12 November 2018, mata pelajaran Fisika pada tanggal 22 November 2018, mata pelajaran Biologi pada tanggal 23 November 2018 dan mata pelajaran Ekonomi dan Sosiologi pada tanggal 24 November 2018. Adapun proses belajar mengajar mengacu pada RPP yang telah dipersiapkan.

\section{Hasil Observasi}

Pengamatan (observasi) dilaksanakan bersamaan dengan kegiatan belajar mengajar. Kegiatan yang diamati difokuskan kepada guru yang melaksanakan proses pembelajaran dengan menggunakan media presentasi microsoft power point dan pengelolaan kelas selama pembelajaran berlangsung. Berdasarkan observasi kinerja mengajar guru pada ke 11 mata pelajaran diperoleh hasil sebagaimana yang diperlihatkan pada Tabel 2.

Tabel 2. Hasil observasi kinerja mengajar guru pada ke 11 mata pelajaran

\begin{tabular}{|c|c|c|c|c|c|c|c|c|c|c|c|}
\hline \multirow{2}{*}{$\begin{array}{r}\text { No } \\
\text { Keg. }\end{array}$} & \multicolumn{11}{|c|}{ Skor/Mata Pelajaran } \\
\hline & $\begin{array}{c}\text { Al- } \\
\text { Qur'an } \\
\text { Hadits }\end{array}$ & $\begin{array}{l}\text { Fi- } \\
\text { qih }\end{array}$ & SKI & B.Ind & B.Ing & $\begin{array}{l}\text { Mate- } \\
\text { matika }\end{array}$ & Kimia & $\begin{array}{c}\text { Fisi } \\
\text { ka }\end{array}$ & Biologi & $\begin{array}{l}\text { Eko- } \\
\text { nomi }\end{array}$ & Sosiologi \\
\hline 1. & 4 & 4 & 4 & 4 & 4 & 4 & 4 & 4 & 4 & 4 & 4 \\
\hline 2. & 4 & 4 & 4 & 3 & 4 & 4 & 4 & 4 & 4 & 4 & 4 \\
\hline 3. & 4 & 1 & 4 & 1 & 4 & 1 & 4 & 1 & 1 & 1 & 4 \\
\hline 4. & 1 & 1 & 4 & 1 & 1 & 1 & 4 & 1 & 1 & 1 & 4 \\
\hline 5. & 4 & 4 & 4 & 4 & 4 & 4 & 4 & 4 & 4 & 4 & 4 \\
\hline 6. & 4 & 4 & 4 & 4 & 4 & 4 & 4 & 4 & 4 & 4 & 4 \\
\hline 7. & 4 & 4 & 4 & 4 & 4 & 4 & 4 & 4 & 4 & 4 & 4 \\
\hline 8. & 4 & 4 & 4 & 4 & 4 & 4 & 4 & 4 & 4 & 4 & 4 \\
\hline 9. & 1 & 1 & 1 & 2 & 4 & 1 & 1 & 1 & 1 & 1 & 3 \\
\hline 10. & 3 & 4 & 4 & 4 & 4 & 4 & 3 & 3 & 4 & 4 & 4 \\
\hline 11. & 3 & 3 & 4 & 3 & 3 & 4 & 3 & 3 & 3 & 4 & 4 \\
\hline 12. & 3 & 3 & 3 & 3 & 3 & 4 & 3 & 3 & 4 & 4 & 4 \\
\hline 13. & 4 & 4 & 4 & 4 & 4 & 4 & 4 & 4 & 4 & 4 & 4 \\
\hline 14. & 4 & 4 & 4 & 4 & 4 & 4 & 4 & 4 & 4 & 4 & 4 \\
\hline 15. & 4 & 4 & 4 & 4 & 4 & 4 & 4 & 4 & 4 & 4 & 4 \\
\hline 16. & 1 & 4 & 4 & 4 & 4 & 4 & 1 & 4 & 3 & 4 & 4 \\
\hline 17. & 4 & 4 & 4 & 4 & 4 & 4 & 4 & 4 & 4 & 4 & 4 \\
\hline 18. & 3 & 3 & 3 & 3 & 3 & 4 & 3 & 3 & 3 & 4 & 3 \\
\hline Total & 59 & 60 & 67 & 60 & 66 & 63 & 62 & 59 & 60 & 63 & 70 \\
\hline
\end{tabular}


Berdasarkan data pada Tabel 2, proses kegiatan belajar mengajar yang dilaksanakan oleh semua guru mata pelajaran yang diobservasi termasuk dalam kategori aktif. Untuk mata pelajaran Al-Qur'an Hadits, 81,94\% keseluruhan item penilaian sudah dilaksanakan dengan baik. Untuk guru mata pelajaran Fiqih $83,33 \%$ keseluruhan item penilaian sudah dilaksanakan dengan baik, guru mata pelajaran SKI sudah melaksanakan 93,05\% keseluruhan item penilaian dengan baik, dan guru mata pelajaran Bahasa Indonesia sudah melaksanakan $83,33 \%$ keseluruhan item penilaian dengan baik.

Adapun guru mata pelajaran Bahasa Inggris sudah melaksanakan 91,66\% keseluruhan item penilaian dengan baik, guru mata pelajaran Matematika melaksanakan 87,50 \% keseluruhan item penilaian dengan baik, dan guru mata pelajaran Kimia melaksanakan dengan baik $86,11 \%$ keseluruhan item penilaian. Demikian pula untuk guru mata pelajaran Fisika $81,94 \%$ keseluruhan item penilaian sudah dilaksanakan dengan baik, guru mata pelajaran Biologi sudah melaksanakan 83,33\% keseluruhan item penilaian dengan baik.

Untuk guru mata pelajaran Ekonomi, 87,50\% keseluruhan item penilaian sudah dilaksanakan dengan baik, dan guru mata pelajaran Sosiologi sudah melaksanakan 97,22\% keseluruhan item penilaian dengan baik. Adapun hasil observasi supervisi tindakan kelas untuk kegiatan penggunaan media presentasi microsoft powerpoint guru ditunjukkan oleh Tabel 3. Berdasarkan data pada Tabel 3 penggunaan media presentasi microsoft power point dalam proses kegiatan belajar mengajar yang dilaksanakan oleh semua guru mata pelajaran yang diobservasi termasuk dalam kriteria nilai 50-60 dengan kategori sangat baik. Untuk guru mata pelajaran Al-Qur'an Hadits 88,33\% keseluruhan item penilaian sudah dilaksanakan dengan baik, guru mata pelajaran Fiqih mampu melaksanakan 96,66\% keseluruhan item penilaian dengan baik dan guru mata pelajaran SKI melaksanakan 83,33\% keseluruhan item penilaian dengan baik. Penggunaan media presentasi microsoft power point dalam proses kegiatan belajar mengajar yang dilaksanakan oleh guru mata pelajaran Bahasa Indonesia 95\% keseluruhan item penilaian sudah dilaksanakan dengan baik, untuk guru mata pelajaran Bahasa Inggris.

Tabel 3. Hasil observasi presentasi

\begin{tabular}{|c|c|c|c|c|c|c|c|c|c|c|c|}
\hline \multirow[b]{2}{*}{ Aspek } & \multicolumn{10}{|c|}{ Skor/Mata Pelajaran } & \multirow[b]{2}{*}{$\begin{array}{r}\text { Sosio- } \\
\text { logi }\end{array}$} \\
\hline & $\begin{array}{l}\text { Qur'an } \\
\text { Hadits }\end{array}$ & Fiqih & SKI & B.Ind & B. Ing & $\begin{array}{c}\text { Mate- } \\
\text { matika }\end{array}$ & Kimia & Fisika & Biologi & $\begin{array}{l}\text { Eko- } \\
\text { nomi }\end{array}$ & \\
\hline 1. Desain slide & 4 & 5 & 3 & 4 & 3 & 3 & 5 & 4 & 5 & 4 & 5 \\
\hline 2. Urutan slide & 5 & 5 & 5 & 5 & 5 & 5 & 5 & 4 & 5 & 5 & 5 \\
\hline 3. Ukuran huruf & 4 & 5 & 4 & 5 & 4 & 3 & 5 & 4 & 4 & 5 & 5 \\
\hline 4. Kesesuaian gambar & 5 & 5 & 3 & 5 & 5 & 4 & 5 & 4 & 5 & 5 & 5 \\
\hline 5. Kontras warna & 3 & 5 & 3 & 4 & 3 & 2 & 5 & 1 & 3 & 5 & 5 \\
\hline 6. Suara & 5 & 5 & 5 & 5 & 5 & 5 & 4 & 5 & 5 & 5 & 5 \\
\hline 7. Kepercayaan diri & 5 & 5 & 5 & 5 & 5 & 5 & 5 & 5 & 5 & 5 & 5 \\
\hline 8. Ekspresi diri & 4 & 5 & 5 & 5 & 5 & 5 & 5 & 5 & 5 & 5 & 5 \\
\hline 9. Kelancaran & 4 & 5 & 5 & 5 & 5 & 5 & 5 & 5 & 5 & 5 & 5 \\
\hline 10. Efektivitas & 5 & 5 & 5 & 5 & 5 & 5 & 4 & 5 & 5 & 5 & 5 \\
\hline 11. Proses tanya jawab & 4 & 5 & 5 & 4 & 3 & 5 & 5 & 5 & 5 & 5 & 5 \\
\hline 12. Kinerja keseluruhan & 5 & 4 & 5 & 5 & 4 & 5 & 5 & 5 & 5 & 5 & 5 \\
\hline Total & 53 & 59 & 53 & 57 & 52 & 52 & 58 & 56 & 57 & 59 & 60 \\
\hline
\end{tabular}

Berdasarkan data pada Tabel 3 penggunaan media presentasi microsoft power point dalam proses kegiatan belajar mengajar yang dilaksanakan oleh semua guru mata pelajaran yang diobservasi termasuk dalam kriteria nilai 50-60 dengan kategori sangat baik. Untuk guru mata pelajaran Al-Qur'an Hadits 88,33\% keseluruhan item penilaian sudah dilaksanakan 
dengan baik, guru mata pelajaran Fiqih mampu melaksanakan 96,66\% keseluruhan item penilaian dengan baik dan guru mata pelajaran SKI melaksanakan 83,33\% keseluruhan item penilaian dengan baik. Penggunaan media presentasi microsoft power point dalam proses kegiatan belajar mengajar yang dilaksanakan oleh guru mata pelajaran Bahasa Indonesia 95\% keseluruhan item penilaian sudah dilaksanakan dengan baik, untuk guru mata pelajaran Kimia 86,66\% keseluruhan item penilaian sudah dilaksanakan dengan baik dan untuk guru mata pelajaran Matematika sudah melaksanakan $86,66 \%$ keseluruhan item penilaian dengan baik.

Penggunaan media presentasi microsoft power point dalam proses kegiatan belajar mengajar yang dilaksanakan oleh guru mata pelajaran Kimia termasuk kategori sangat baik. Artinya 96,66\% keseluruhan item penilaian sudah dilaksanakan dengan baik. Untuk guru mata pelajaran Fisika 93,33\% keseluruhan item penilaian sudah dilaksanakan dengan baik, guru mata pelajaran Biologi sudah melaksanakan 95\% keseluruhan item penilaian dengan baik.

Hasil ini didukung oleh hasil penelitian Soramiranda, Ningsih, \& Panjaitan (2016) yang menyatakan bahwa penggunaan media powerpoint disertai kartu bergambar dapat meningkatkan hasil belajar siswa dengan rata- rata skor post-test sebesar 15,55. Lebih lanjut, media powerpoint disertai kartu bergambar juga efektif dalam meningkatkan hasil belajar siswa dan memberikan kontribusi terhadap hasil belajar sebesar 32,64\%.

Selain itu hasil penelitian Orhan (2016) juga menemukan bahwa bahwa aktivitas peserta didik di kelas XI IPS-4 SMAN 2 Palangka Raya lebih aktif dan antusias dalam pembelajaran dengan menggunakan media Power Point. Aktivitas peserta didik siklus I skor rata-rata 81,58\% dengan kategori baik, siklus II nilai rata-rata 97,37\% dengan kategori sangat baik. Ada peningkatan hasil belajar ekonomi dengan menggunakan media Power Point pada kelas XI IPS-4 SMAN 2 Palangka Raya Tahun Pelajaran 2014/2015. Nilai rata- rata kelas pra tindakan 62,03 dengan ketuntasan klasikal 40\%, siklus I nilai rata- rata 80,62 dengan ketuntasan klasikal 62,5\%, dan siklus II rata-rata kelas 89,68 dengan ketuntasan 90\%. Demikian pula penelitian Yulianti (2017) menyatakan bahwa pengembangan media presentasi visual powerpoint for android dengan pendekatan kontekstual valid digunakan dan efektif serta praktis dari pada pendekatan saintifik pada pembelajaran matematika di SMP.

Penggunaan media presentasi microsoft power point dalam proses kegiatan belajar mengajar yang dilaksanakan oleh guru mata pelajaran Bahasa Indonesia termasuk dalam kategori sangat baik. Dari keseluruhan item penilaian, 98,33\% sudah dilaksanakan dengan baik. Hal ini didukung oleh hasil penelitian Permatasari (2014) tentang kemampuan rata- rata menulis cerita pendek di kelas VII SMPN I Tarogong Kaler setelah menggunakan pembelajaran dengan multimedia PowerPoint termasuk kategori baik dan melampaui kriteria kemampuan minimal. Terdapat pengaruh yang signifikan antara kemampuan menulis cerita pendek sebelum menggunakan multimedia PowerPoint dengan kemampuan menulis cerita pendek setelah menggunakan multimedia PowerPoint pada siswa di kelas 7 SMPN I Tarogong Kaler.

Adapun penggunaan media presentasi microsoft power point dalam proses kegiatan belajar mengajar yang dilaksanakan oleh guru mata pelajaran Fisika memperoleh nilai 60, artinya $100 \%$ keseluruhan item penilaian sudah dilaksanakan dengan baik.

\section{Refleksi}


Hasil refleksi terhadap hasil observasi dan evaluasi pada mata pelajaran Pendidikan Al-Qur'an Hadits menunjukkan bahwa:

a) Proses kegiatan belajar mengajar guru mata pelajaran Al-Qur'an Hadits termasuk dalam kategori aktif karena $81,94 \%$ semua item terlaksana dengan baik.

b) Pengolahan dan penyajian media presentasi microsoft powerpoint dalam pembelajaran termasuk kategori sangat baik karena $88,33 \%$ semua item terpenuhi.

c) Indikator keberhasilan kinerja guru tercapai, dimana perolehan hasil supervisi tindakan untuk proses $\operatorname{KBM}(81,94 \%)$ dan pengolahan/penyajiaan media presentasi $(88,33 \%)$ berada di atas indikator keberhasilan kinerja guru yaitu $80 \%$ dan $75 \%$.

Adapun refleksi terhadap hasil evaluasi dan observasi pada mata pelajaran Fiqih adalah:

a) Proses kegiatan belajar mengajar guru mata pelajaran Fiqih termasuk dalam kategori aktif karena 83,33\% semua item terlaksana dengan baik.

b) Pengolahan dan penyajian media presentasi microsoft powerpoint dalam pembelajaran termasuk kategori sangat baik karena 96,66\% semua item terpenuhi.

c) Indikator keberhasilan kinerja guru tercapai, dimana perolehan hasil supervisi tindakan untuk proses $\mathrm{KBM}(83,33 \%)$ dan pengolahan/penyajiaan media presentasi $(96,66 \%)$ berada di atas indikator keberhasilan kinerja guru yaitu $80 \%$ dan $75 \%$.

Hasil refleksi terhadap hasil observasi dan evaluasi pada mata pelajaran SKI menunjukkan bahwa:

a) Proses kegiatan belajar mengajar guru mata pelajaran SKI dalam kategori aktif karena 93,05\% semua item terlaksana dengan baik.

b) Pengolahan dan penyajian media presentasi microsoft powerpoint dalam pembelajaran termasuk kategori sangat baik karena 83,33\% semua item terpenuhi.

c) Indikator keberhasilan kinerja guru tercapai, dimana perolehan hasil supervisi tindakan untuk proses $\mathrm{KBM}(93,05 \%)$ dan pengolahan/penyajiaan media presentasi $(83,33 \%)$ berada di atas indikator keberhasilan kinerja guru yaitu $80 \%$ dan $75 \%$.

Adapun refleksi terhadap hasil observasi dan evaluasi pada mata pelajaran Bahasa Indonesia menunjukkan bahwa:

a) Proses kegiatan belajar mengajar guru mata pelajaran Bahasa Indonesia termasuk dalam kategori aktif karena 83,33\% semua item terlaksana dengan baik.

b) Pengolahan dan penyajian media presentasi microsoft powerpoint dalam pembelajaran termasuk kategori sangat baik karena 95\% semua item terpenuhi.

c) Indikator keberhasilan kinerja guru tercapai, dimana perolehan hasil supervisi tindakan untuk proses $\mathrm{KBM}(83,33 \%)$ dan pengolahan/penyajiaan media presentasi $(95 \%)$ berada di atas indikator keberhasilan kinerja guru yaitu $80 \%$ dan $75 \%$.

Hasil refleksi terhadap hasil observasi dan evaluasi pada mata pelajaran Bahasa Inggris menunjukkan bahwa:

a) Proses kegiatan belajar mengajar guru mata pelajaran Bahasa Inggris termasuk dalam kategori aktif karena 91,66\% semua item terlaksana dengan baik.

b) Pengolahan dan penyajian media presentasi microsoft powerpoint dalam pembelajaran termasuk kategori sangat baik karena 86,66\% semua item terpenuhi.

c) Indikator keberhasilan kinerja guru tercapai, dimana perolehan hasil supervisi tindakan untuk proses $\mathrm{KBM}(91,66 \%)$ dan pengolahan/penyajiaan media presentasi $(86,66 \%)$ berada di atas indikator keberhasilan kinerja guru yaitu $80 \%$ dan $75 \%$.

Refleksi terhadap hasil observasi dan evaluasi pada mata pelajaran Matematika 
menunjukkan bahwa:

a) Proses kegiatan belajar mengajar guru mata pelajaran Matematika termasuk dalam kategori aktif karena 87,50\% semua item terlaksana dengan baik.

b) Pengolahan dan penyajian media presentasi microsoft powerpoint dalam pembelajaran termasuk kategori sangat baik karena 86,66\% semua item terpenuhi.

c) Indikator keberhasilan kinerja guru tercapai, dimana perolehan hasil supervisi tindakan untuk proses $\mathrm{KBM}(87,50 \%)$ dan pengolahan/penyajiaan media presentasi $(86,66 \%)$ berada di atas indikator keberhasilan kinerja guru yaitu $80 \%$ dan $75 \%$.

Refleksi terhadap hasil observasi dan evaluasi pada mata pelajaran Kimia menunjukkan bahwa:

a) Proses kegiatan belajar mengajar guru mata pelajaran Kimia termasuk dalam kategori aktif karena $86,11 \%$ semua item terlaksana dengan baik.

b) Pengolahan dan penyajian media presentasi microsoft powerpoint dalam pembelajaran termasuk kategori sangat baik karena 96,66\% semua item terpenuhi.

c) Indikator keberhasilan kinerja guru tercapai, dimana perolehan hasil supervisi tindakan untuk proses $\mathrm{KBM}(86,11 \%)$ dan pengolahan/penyajiaan media presentasi $(96,66 \%)$ berada di atas indikator keberhasilan kinerja guru yaitu $80 \%$ dan $75 \%$.

Hasil refleksi terhadap hasil observasi dan evaluasi pada mata pelajaran Fisika menunjukkan bahwa:

a) Proses kegiatan belajar mengajar guru mata pelajaran Fisika termasuk dalam kategori aktif karena $81,94 \%$ semua item terlaksana dengan baik.

b) Pengolahan dan penyajian media presentasi microsoft powerpoint dalam pembelajaran termasuk kategori sangat baik karena 93,33\% semua item terpenuhi.

c) Indikator keberhasilan kinerja guru tercapai, dimana perolehan hasil supervisi tindakan untuk proses $\mathrm{KBM}(81,94 \%)$ dan pengolahan/penyajiaan media presentasi $(93,33 \%)$ berada di atas indikator keberhasilan kinerja guru yaitu $80 \%$ dan $75 \%$.

Hasil refleksi terhadap hasil observasi dan evaluasi pada mata pelajaran Biologi menunjukkan bahwa:

a) Proses kegiatan belajar mengajar guru mata pelajaran Biologi termasuk dalam kategori aktif karena $83,33 \%$ semua item terlaksana dengan baik.

b) Pengolahan dan penyajian media presentasi microsoft powerpoint dalam pembelajaran termasuk kategori sangat baik karena 95\% semua item terpenuhi.

c) Indikator keberhasilan kinerja guru tercapai, dimana perolehan hasil supervisi tindakan untuk proses $\mathrm{KBM}(83,33 \%)$ dan pengolahan/penyajiaan media presentasi $(95 \%)$ berada di atas indikator keberhasilan kinerja guru yaitu $80 \%$ dan $75 \%$.

Hasil refleksi terhadap hasil observasi dan evaluasi pada mata pelajaran Ekonomi menunjukkan bahwa:

a) Proses kegiatan belajar mengajar guru mata pelajaran Ekonomi termasuk dalam kategori aktif karena $87,50 \%$ semua item terlaksana dengan baik.

b) Pengolahan dan penyajian media presentasi microsoft powerpoint dalam pembelajaran termasuk kategori sangat baik karena 98,33\% semua item terpenuhi.

c) Indikator keberhasilan kinerja guru tercapai, dimana perolehan hasil supervisi tindakan untuk proses $\mathrm{KBM}(87,50 \%)$ dan pengolahan/penyajiaan media presentasi $(98,33 \%)$ berada di atas indikator keberhasilan kinerja guru yaitu $80 \%$ dan $75 \%$.

Refleksi terhadap hasil observasi dan evaluasi pada mata pelajaran Sosiologi menunjukkan bahwa: 
a) Proses kegiatan belajar mengajar guru mata pelajaran Sosiologi termasuk dalam kategori aktif karena 97,22\% semua item terlaksana dengan baik.

b) Pengolahan dan penyajian media presentasi microsoft powerpoint dalam pembelajaran termasuk kategori sangat baik karena $100 \%$ semua item terpenuhi.

c) Indikator keberhasilan kinerja guru tercapai, dimana perolehan hasil supervisi tindakan untuk proses $\mathrm{KBM}(97,22 \%)$ dan pengolahan/penyajiaan media presentasi $(100 \%)$ berada di atas indikator keberhasilan kinerja guru yaitu $80 \%$ dan $75 \%$.

Berdasarkan hasil penelitian tindakan sekolah secara keseluruhan, 11 orang guru mata pelajaran yang dipilih sebagai subyek penelitian menunjukkan kinerja mengajar yang baik. Proses kegiatan belajar mengajar guru mata pelajaran yang menerapkan penggunaan media presentasi microsoft powerpoint dalam pembelajarannya sudah memenuhi item-item penilaian kinerja guru dalam mengajar. Indikator keberhasilan kinerja guru dianggap baik dan meningkat bila memperoleh nilai $\geq 58$ dengan persentase $80 \%$.

Berdasarkan data grafik 2 di atas dapat dijabarkan bahwa ada 2 orang guru mata pelajaran, yaitu Al-Qur'an Hadits dan Kimia yang mendapatkan nilai 59 dengan prosentasi item penilaian yang terpenuhi keseluruhan $81,94 \%$. Ada 3 orang guru mata pelajaran, yaitu Fiqih, Bahasa Indonesia dan Fisika mendapatkan nilai 60 dengan prosentasi item penilaian yang terpenuhi keseluruhan $83,33 \%$. Ada 1 orang guru mata pelajaran Kimia mendapatkan nilai 62 dengan prosentasi item penilaian yang terpenuhi keseluruhan 86,11\%. Kemudian 2 orang guru mata pelajaran, Matematika dan Ekonomi memperoleh nilai 63 dengan prosentasi item penilaian yang terpenuhi sebesar $87,50 \%$. Lalu ada 1 orang guru mata pelajaran Bahasa Inggris memperoleh nilai dari hasil supervisi tindakan kelas 66 dengan prosentasi dari item yang terlaksana $91,66 \%$, selanjutnya 1 orang guru mata pelajaran SKI dengan nilai 67 atau 93,05\% item penilaian sudah terpenuhi. Terakhir 1 orang guru mata pelajaran Sosiologi memperoleh nilai supervisi tindakan kelas 70 atau 97,22 item penilaian dalam lembar obervasi terlaksana dengan gan baik.

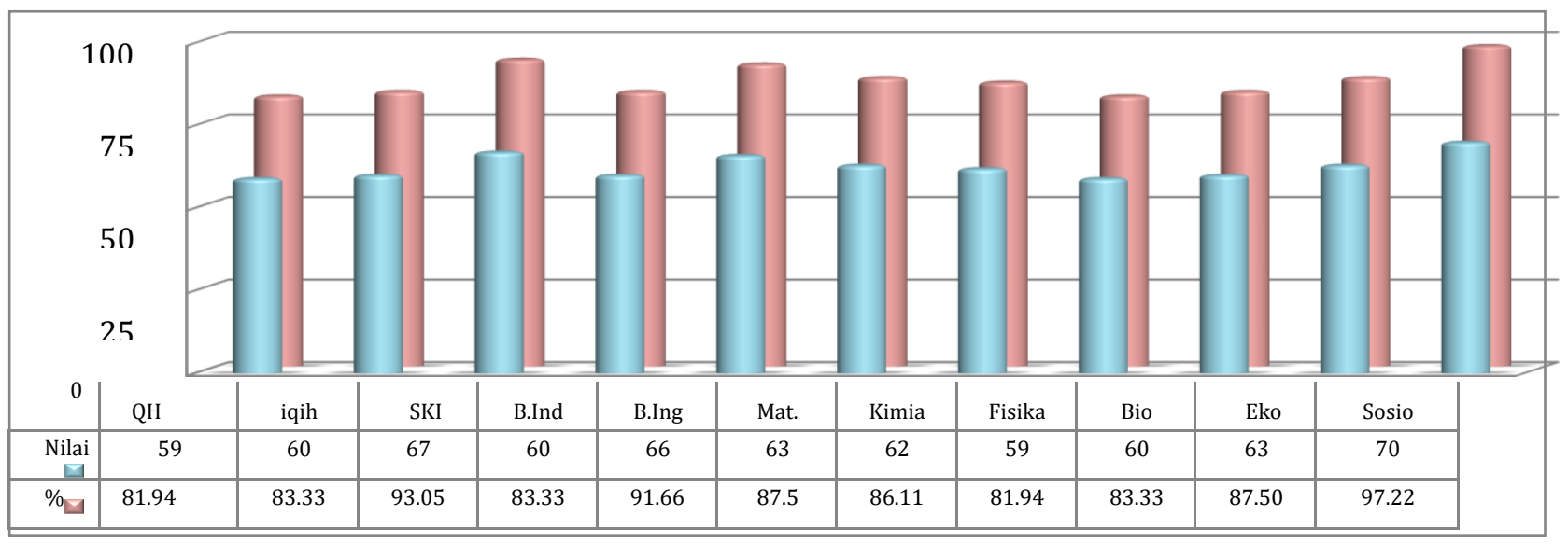

Gambar 2. Grafik Perbandingan Hasil Kegiatan Belajar Mengajar Guru

Dari uraian di atas dapat disimpulkan bahwa semua guru mata pelajaran yang melaksanakan proses kegiatan belajar mengajar dengan menggunakan media presentasi microsoft powerpoint sudah melaksanakan dengan baik dan mengalami peningkatan.

\section{Kemampuan Guru Menggunakan Media Microsoft Powerpoint}

Berdasarkan hasil supervisi kelas yang dilakukan oleh peneliti yang mengacu pada lembar observasi pembuatan dan penyajian media presentasi microsoft power point dalam kegiatan pembelajaran, secara keseluruhan (11 orang) guru mata pelajaran yang dipilih 
sebagai subyek penelitian menunjukkan kinerja guru yang baik, khususnya terampil dalam hal pembuatan dan penyajian media presentasi microsoft powerpoint.

Kemampuan dalam hal mengolah media seperti; desain, pemilihan jenis huruf, pemilihan dan peletakan gambar sesuai dengan materi dan animasi. Penyajian media presentasi microsoft powerpoint seperti; suara, ekspresi dan gaya serta efektifitas dalam mengajar sudah memenuhi item-item penilaian. Indikator keberhasilan kinerja guru dalam pembuatan dan penyajian media presentasi microsoft powerpoint dianggap baik dan meningkat bila memperoleh nilai $\geq 45$ dengan prosentasi $75 \%$.

Berdasarkan grafik pada gambar 3, dapat dijelaskan bahwa baik nilai maupun persentase kinerja guru guru mata pelajaran untuk hal pembuatan dan penyajian media presentasi microsoft power point dalam Mengajar sudah tercapai dan terlaksana dengan baik. Sebelas orang guru yang menjadi subyek penelitian ini memperlihatkan kemampuan dan kompetensi mereka dalam hal pengolahan media.

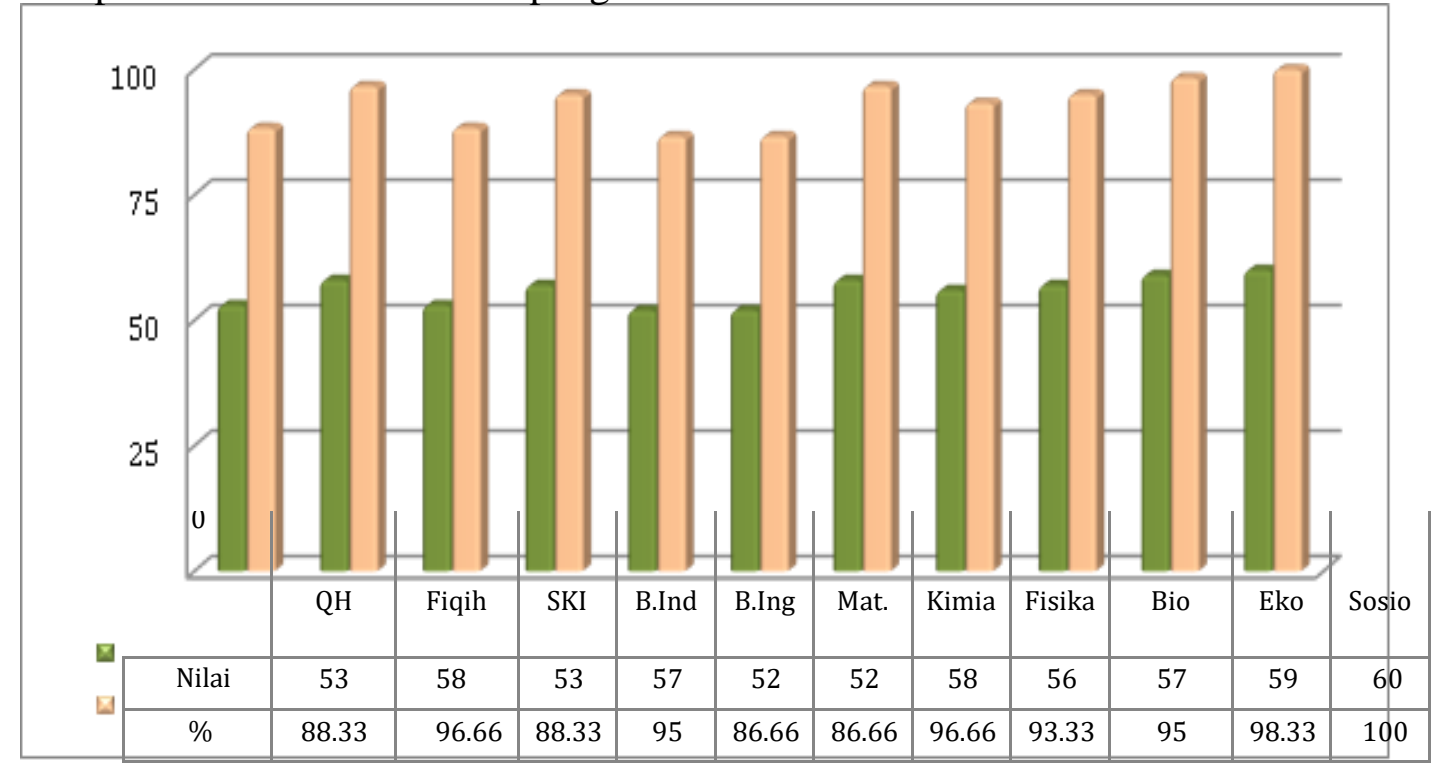

Gambar 3. Hasil Pembuatan dan Penyajian Media

Perolehan nilai 52 dengan prosentasi pemenuhan item-item penilaian kinerja guru mata pelajaran terhadap pembuatan dan penyajian media presentasi microsoft powerpoint $86,66 \%$ ada 2 orang guru mata pelajaran, yaitu Bahasa Inggris dan Matematika. Dua orang guru mata pelajaran, yaitu Al-Qur'an Hadits dan SKI mendapatkan jumlah nilai 53 dengan persentasi 88,33 \% item penilaian sudah terlaksana dengan baik, dan satu orang guru mata pelajaran Kimia memperoleh persentasi $93,33 \%$ untuk pencapaian penilaian kinerja dengan nilai 56. Dari 11 orang subyek penelitian, ada 3 orang guru mata pelajaran yang memperoleh nilai dan persentase mendekati kategori sangat baik, yaitu Bahasa Indonesia dan Biologi mendapatkan nilai 57 untuk penilaian kinerja guru dengan persentasi 95\%, serta mata pelajaran Ekonomi dengan perolehan nilai 59 dengan persentase 98,33\%. Selanjutnya, 1 orang guru mata pelajaran Sosiologi termasuk kategori sangat baik dengan perolehan nilai 60 untuk penilaian kinerja guru dalam hal pembuatan dan penyajian media presentasi atau dengan persentase $100 \%$ seluruh item terlaksana dengan baik.

Temuan ini senada dengan penelitian Endrawati \& Suartana (2016) yang menyatakan bahwa terjadi peningkatkan kreativitas belajar setelah diterapkan model pembelajaran berbasis masalah berbantuan media power point pada siswa kelas XI.3 jasa boga 3 SMK Negeri 2 Tabanan. Hal ini dilihat dari meningkatnya kreativitas belajar siswa pada siklus I 
dari rata-rata $73,25 \%$ dengan kategori baik menjadi rata0rata $85,62 \%$ pada siklus II dengan kategori sangat baik. Ini menunjukkan bahwa telah terjadi peningkatan kreativitas belajar siswa pada siklus II, dengan rata-rata peningkatan sebesar $12,37 \%$. Penerapan pembelajaran menggunakan media power berhasil dengan katogeri baik.

Kenyataan ini didasarkan pada data hasil penelitian tindakan sekolah dalam bentuk supervisi kelas yang tergambar pada gambar 3, dimana nilai dan persentase guru mata pelajaran sesuai dengan indikator keberhasilan dalam penelitian, yaitu nilai $\geq 45$ dengan persentase $75 \%$. Mengacu pada indikator keberhasilan penelitian tindakan sekolah di atas maka dapat dikatakan bawa semua subyek penelitian yang terdii atas 11 orang guru mata pelajaran mempunyai kemampuan dan kompetensi yang baik.

\section{KESIMPULAN}

Melihat data perolehan hasil penelitian dalam kegiatan penelitian tindakan sekolah ini, dapat disimpulkan bahwa supervisi akademik yang dilakukan oleh kepala sekolah terhadap 11 orang guru mata pelajaran berhasil meningkatkan kinerja guru dalam membuat, menyajikan dan menggunakan media presentasi microsoft powerpoint dalam mengajar. Kemampuan kinerja guru mata pelajaran dalam melaksanakan proses kegiatan belajar mengajar dengan menggunakan media presentasi microsoft powerpoint meningkat dari skor $59(81,94 \%)$ menjadi 70 (97,22\%) pada akhir kegiatan supervisi. Pada aspek pembuatan dan penyajian materi pembelajaran, terdapat peningkatan kemampuan kinerja guru dari nilai $52(86,66 \%)$ menjadi $60(100 \%)$.

\section{DAFTAR PUSTAKA}

Endrawati, N. N., \& Suartana, I. K. (2016). Penerapan Model Pembelajaran Berbasis Masalah Berbantuan Media Power Point untuk Meningkatkan Kreativitas dan Hasil Belajar Siswa di SMK Negeri 2 Tabanan. Jepun: Jurnal Pendidikan Universitas Dhyana Pura, $1-16$.

Harjanto. (2008). Perencanaan Pengajaran. Jakarta: Rineka Cipta.

Hartini. (2017). Upaya Meningkatkan Kinerja Guru Mengajar Melalui Pembinaan Konsep dan Implementasi Media Presentasi Microsoft Powerpoint di SMA Negeri 1 Banjarmasin. Vidya Karya, 178-189.

Kemmis, S., McTaggart, R., \& Nixon, R. (2014). The Action Research Planner. London: Springer.

Mukhlis, M. (2008). KTSP Pembelajaran Berbasis Kompetensi dan Kontekstual. Jakarta: Bumi Aksara.

Orhan. (2016). Upaya Meningkatkan Hasil Belajar Ekonomi Dengan Menggunakan Media Power Point. Neraca: Jurnal Pendidikan Ekonomi, 19-23.

Permatasari, A. A. (2014). Pengaruh Penggunaan Multimedia Powerpoint Terhadap Peningkatan Kemampuan Menulis Cerita Pendek Pada Pembelajaran Bahasa Indonesia. Pedagogia: Jurnal Ilmu dan Pendidikan, 19-23.

Sadirman, S. A., \& dkk. (2003). Media Pendidikan. Jakarta: Raja Grafindo Persada.

Sanjaya, W. (2010). Strategi Pembelajaran Berorientasi Standar Proses Pendidikan. Jakarta: Kencana. 
Soramiranda, N., Ningsih, K., \& Panjaitan, R. (2016). Efektivitas Penggunaan Media Powerpoint Disertai Kartu Bergambar Terhadap Hasil Belajar Siswa pada Materi Klasifikasi Makhluk Hidup di Kelas VII SMPN 2 Ketapang. Jurnal Lensa, 77-83.

Yulianti. (2017). Pengembangan Media Presentasi Visual dengan Pendekatan Kontekstual dalam Pembelajaran Matematika di SMP. Journal of Mathematics Education, Science and Technology, 231-242. 